\title{
Effect of Doxorubicin on the morphology, histology and karyology of male reproductive system of white mice, Mus musculus
}

\author{
Thiagarajan.Sridevi ${ }^{1}$, P.V. Nisha ${ }^{2}$ and G. Appavu Arulnathan ${ }^{3}$ \\ ${ }^{1}$ Department of Advanced Zoology \& Biotechnology, Quaid-E-Millat Govt. College (W), Chennai-600 002, India \\ ${ }^{2}$ Bharathiar University, Coimbatore- 641 047, India \\ ${ }^{3}$ Dean of Sciences, PRIST University, Thanjavur- 613403 India \\ thiagarajan_sridevi@yahoo.com
}

\begin{abstract}
Doxorubicin (adriamycin) an anti tumour antibiotic is effective against solid and non- solid malignant tumour. It is known to produce reproductive toxicity. An attempt has been made to study the effect of Doxorubicin on the histological and morphometric changes in the male reproductive system and karyological changes in the bone marrow of mice, Mus musculus at the prescribed dosage of $0.5-1 \mathrm{mg} / \mathrm{kg}$ body weight. The histological observations in the present studies showed no apparent damage to the testis and there was no difference in spermatogonial, spermatocyte or spermatid population. Epididymis and the seminal vesicle too showed no apparent damage in the dosage studied. Chromosome analysis of the bone marrow cells did not show any significant aberrations. At the dose designed in the present investigation all the changes observed were transitory and did not impair the normal functioning of the reproductive tissues.
\end{abstract}

Keywords. Doxorubicin, histology, testis, morphometry , karyology

\section{Introduction}

Cancer remains a hugely expensive public health problem both in terms of economy and the amount of human suffering it produces (Weiss, 1995). McGardy (1993) aptly describes a cancer cell as "a savage cell which somehow corrupts the forces which normally protects the body, invades the well ordered society of cells surrounding it, colonizes distant areas and as a finale to its cannibalistic orgy of flesh consuming flesh, commits suicide by destroying the host."

Gonadal injury by antineoplastic drugs like Doxorubicin, though commonly observed, has been relatively less investigated when compared to their other adverse effect (Ward et al., 1988). Doxorubicin exhibits profound toxicity to the reproductive system, adversely affecting male fertility (Shamberger et al., 1981). Doxorubicin is very effective, but exhibits reproductive toxicity at high doses (Lu \& Meistrich, 1979; Meistrich, 1982; Ward et al., 1988).

Doxorubicin causes severe degenerative changes in germinative cells, atrophy in the diameter size of seminiferous tubules and germinative cell thickness. Meistrich et al., (1990) showed that translocations could result in heritable mutations and doxorubicin elevated DNA fragmentation and toxicity. Kamendulis et al., (1994) proved that DNA damage is an early causal event in toxic cell death caused by alkylating hepatotoxicants. At doses of $6 \mathrm{mg} / \mathrm{kg}$, doxorubicin is a weak inducer of chromosomal mutation (Meistrich et al., 1990).

Although the above data indicate that doxorubicin is a testicular toxicant which is dose dependent not much work has been carried out to study the effects of Doxorubicin at the recommended therapeutic doses.
Therefore an attempt has been made to study the histological and morphometric changes in the tissues related to the male reproductive system and the karyological changes in the somatic cells of the bone marrow and the effect after the cessation of the administration of the drug.

Materials and methods Experimental animal and laboratory maintenance

Male white mice of inbred Swiss strain, $45 \pm 5$ days old and of $30 \pm 5$ gm body weight were selected and used for experiment. The animals were obtained from Fredrick Institute of Plant Protection and Toxicology (FIPPAT), Padapai. The animals were housed in polypropylene cages and provided with standard pelletized feed. Food and water were provided ad libitum.

Experimental design

The animals were divided into three groups. The group I $(0.9 \%$ saline, intraperitoneally, every 24 hours and sacrificed on the $6^{\text {th }}$ day), group II $(0.5 \mathrm{mg} / \mathrm{kg}$ of Doxorubicin intraperitoneally, every 24 hours and sacrificed on the $6^{\text {th }}$ day) and group III $(0.5 \mathrm{mg} / \mathrm{kg}$ intraperitoneally, every 24 hours for 5 days with a withdrawal period of 6 days and sacrificed on the $13^{\text {th }}$ day).

Methodology

Doxorubicin has been given in doses of $0.5-1 \mathrm{mg} / \mathrm{kg}$ daily for 2-6 days (Goodman and Gilman, 1975) Based on this a dose of $0.02 \mathrm{mg} /$ animal was obtained for the present study by dissolving $1.0 \mathrm{mg}$ of Doxorubicin in $5 \mathrm{ml}$ of $0.9 \%$ saline. $0.01 \mathrm{ml}$ of this solution was administered intraperitoneally with a 25 gauge needle with a disposable syringe. The animals were sacrificed by cervical dislocation. The tissues like the testis, seminal
Research article

(C)Indian Society for Education and Environment (iSee)
"Doxorubicin on mice" http://www.indjst.org
T.Sridevi et al. Indian J.Sci.Technol. 
vesicle and epididymis were immediately removed, cleaned from the adhering tissue and weighed individually. The organs and tissues were processed for histological studies as per the methods of Pearse (1980; 1985). The volume estimation of the various regions of the male reproductive system was done according to the principles of Elias \& Pauly (1966).Chromosome preparation and aberration scoring was done according to the methods of Murthy (1983).

Data analyses were carried out using SPSS statistical package. Analysis of variance (ANOVA) was used to determine differences between various data sets. Tukey's multiple range test was used to resolve

Table 1. Effect of Doxorubicin on the body weight (in gms) of white mice, Mus musculus

\begin{tabular}{|c|c|}
\hline & Body Weight \\
\hline Group - I & $33.69 \pm 1.03(\mathrm{a})$ \\
\hline Group - II & $30.67 \pm 0.21(\mathrm{~b})$ \\
\hline Group - III & $30.64 \pm 0.42(\mathrm{~b})$ \\
\hline
\end{tabular}

The given values are Mean $\pm S D$, Means within a column with different letters are significant $(p<0.05)$

difference among treatment mean. A value of $p<0.05$ was used to indicate significant difference.

\section{Results and discussion}

\section{Body weight and tissues}

The effect of Doxorubicin on the body weight and the weight of various tissues are shown in the Table $1 \& 2$. Doxorubicin administration produced a significant decrease in the body weight. The overall trend showed a decrease in the individual tissue weights too. The reduction in weight was significant in all the tissue studied except cauda and corpus. The weight of the body and the tissues of group III increased when compared to the group II except in cauda and corpus. The group III animals may reach the weight of the group I animals if sufficient time is given. Pristos et al., (1992) have shown Doxorubicin induced decrease in body weight in mice. Ward et al., (1998) also reported a dose related reduction in the weight of testis epididymis and seminal vesicle at the dose of $1 \mathrm{mg} / \mathrm{kg}$ body weight.

\section{Histology}

The results of the histological preparation of the testis from Doxorubicin are shown in Plate $1 \&$ Fig 1 . The testis shows that there is no observable difference between the groups with regard to spermatogonial, spermatocyte or spermatid population. Leydig cells show a marginal degeneration in the group II which show recovery in the group III. Ward et al., (1998) illustrated the presence of large vacuoles in the cytoplasm of Sertoli cells is indicative of spermatogenic epithelial degeneration and is

Table 2. Effect of Doxorubicin on the total organ / tissue weight (in

\begin{tabular}{|c|c|c|c|c|c|}
\hline & Testis & Caput & Corpus & Cauda & Seminal Vesicle \\
\hline Group - I & $109.72 \pm 0.74(\mathrm{a})$ & $31.67 \pm 1.05(\mathrm{a})$ & $4.10 \pm 0.36(\mathrm{a})$ & $33.66 \pm 0.13(\mathrm{a})$ & $163.73 \pm 3.65(\mathrm{a})$ \\
\hline Group - II & $97.03 \pm 2.35(\mathrm{~b})$ & $28.40 \pm 0.50(\mathrm{a})$ & $4.00 \pm 0.10(\mathrm{a})$ & $29.90 \pm 0.21(\mathrm{~b})$ & $144.27 \pm 1.35(\mathrm{~b})$ \\
\hline Group- III & $109.70 \pm 1.8(\mathrm{a})$ & $31.45 \pm 2.31(\mathrm{a})$ & $4.07 \pm 0.06(\mathrm{a})$ & $30.91 \pm 1.54(\mathrm{~b})$ & $155.17 \pm 0.75(\mathrm{c})$ \\
\hline
\end{tabular}

The given values are Mean $\pm S D$; Means within a column with different letters are significant $(p<0.05)$

Research article

Clndian Society for Education and Environment (iSee)
Effect of Doxorubicn on the histology of the various regions of the male reproductive system of the white mice Mus musculus

Fig. 1. Section of Testis

Fig.2. Section of caput
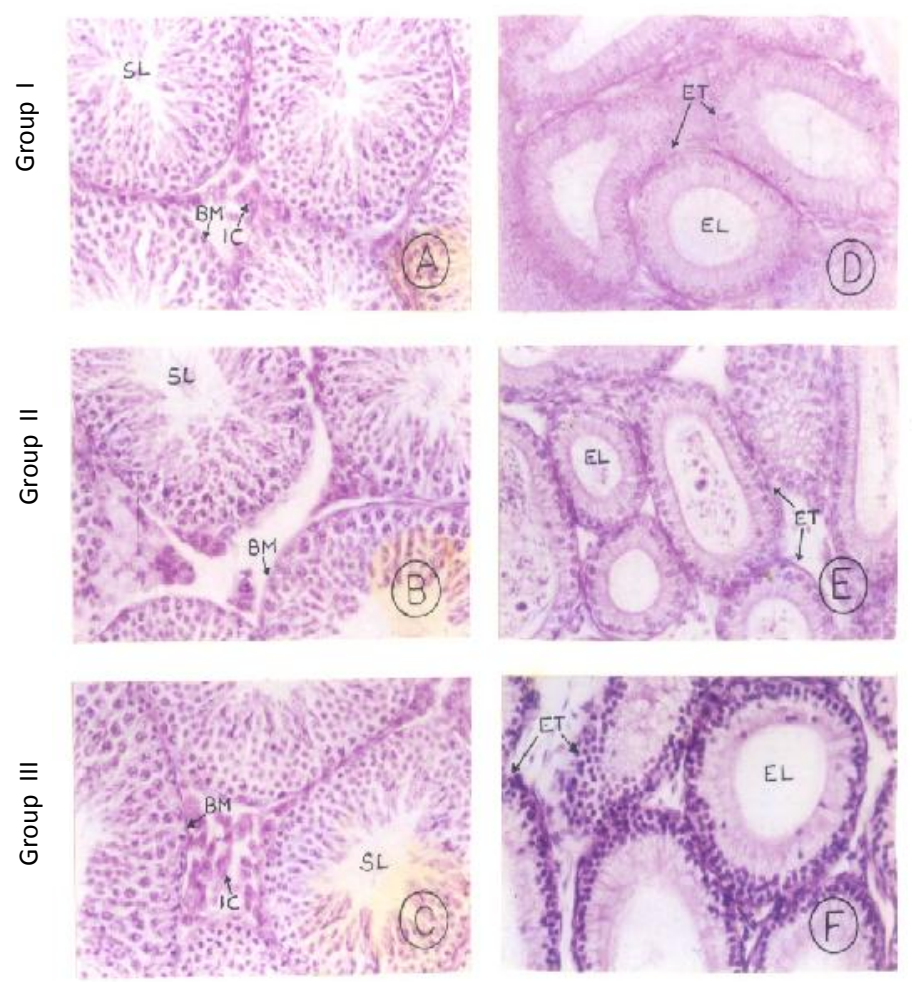

SL: Seminifereous lumen; IC: Interstitial cells; BM: Basement membrane ET: Epididymal tubule; SL: Seminal vesicle lumen; EL: Epididymal lumen

dose related. Patil and Balaraman (2009) have reported vacuolization and fibrinoid debris in the seminiferous tubule when male rats were treated with $15 \mathrm{mg} / \mathrm{kg}$ of Doxorubicin. Sonmez et al. (2005) and Saalu et al. (2006) have reported that germinal epithelium is more sensitive to cytotoxic drugs and oxidative stress. At low doses there are no large vacuole formations but on increasing the dose from $3 \mathrm{mg} / \mathrm{kg}$ to $12 \mathrm{mg} / \mathrm{kg}$, the number of these large vacuoles increases extensively. No such vacuoles could be observed in the present study and no apparent damage to the testicular tissue could be detected in the experimental group. In accordance to the literature cited, the low dose of doxorubicin employed in the present study could be a possible explanation for the absence of any testicular damage. 


\section{Effect of Doxorubicn on the histology of the various regions of the male reproductive system of the white mice Mus} musculus

Fig. 3. Section of Corpus
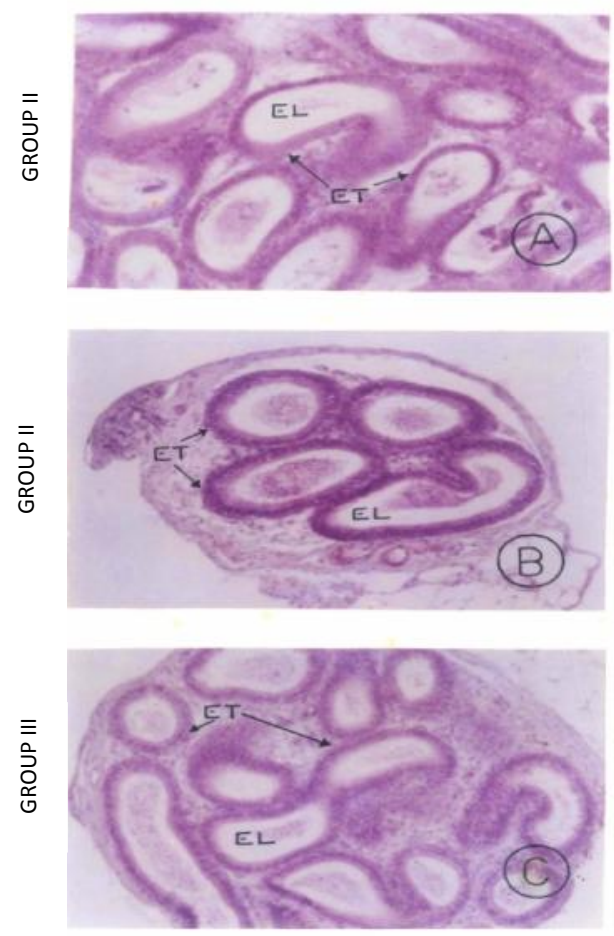

Fig. 4. Section of Cauda
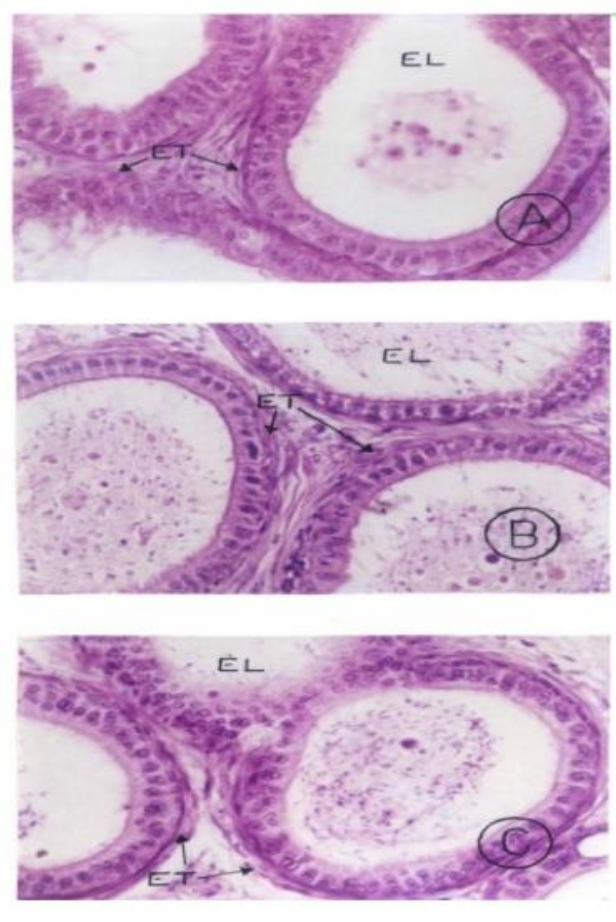

Fig. 5. Section of Seminal vesicle
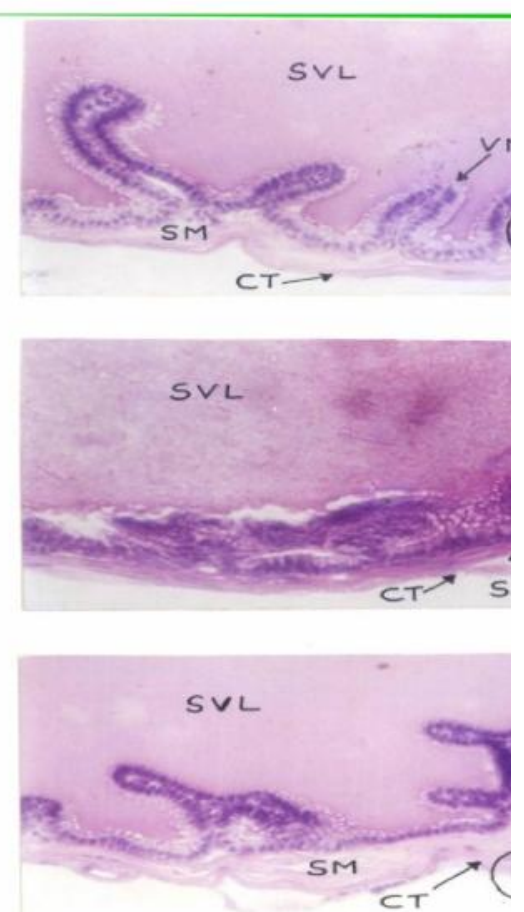

SL: Seminifereous lumen; IC: Interstitial cells; BM: Basement membrane;

EL: Epididymal lumen; ET: Epididymal tubule; SVL: Seminal vesicle lumen; VM: Villous mucosa;

SM: Smooth muscle layer

Fig. 6. Effect of Doxorubicin on the volume (in $\mathrm{mm} 2 / \mathrm{cu} . \mathrm{mm}$ ) of the various region of the male reproductive system of Mus musculus

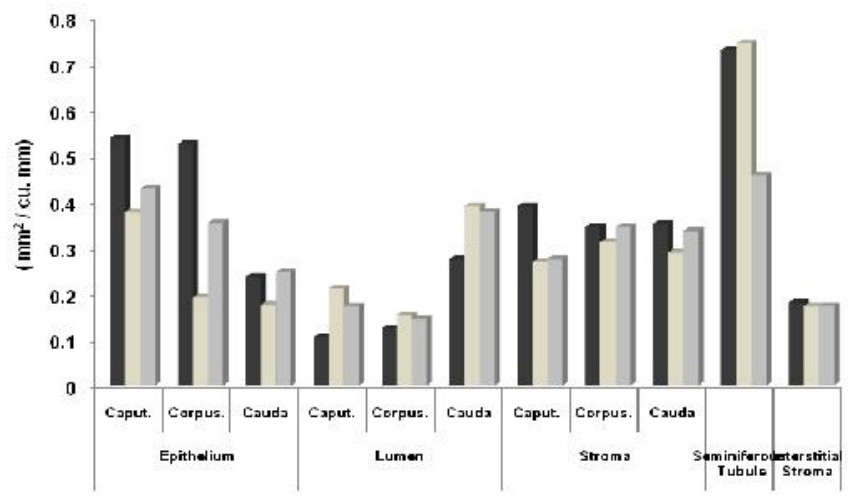

Sections of caput epididymis (Fig. 2) show no observable difference in the histological preparations, between all the three groups. Neither the columnar principal cells with microvilli nor the sperms in the lumen show any change. The same is true of the corpus and the cauda (Fig. $3 \& 4$ ). Sections of the corpus however presented an interesting observation. The overall size of the corpus showed remarkable difference between the Research article CIndian Society for Education and Environment (iSee)

three groups. The corpus of group III showed a decrease in size with deterioration of most of the tubules when compared to the group I, while group III showed an increase in the corpus size as well as the number of tubules with respect to the experimental. However, it never reached the size of the group I. Considering only the histological details no apparent drug effect could be accounted for in the epididymis. However, to decide if the changes in the size of the corpus epididymis of the treated animals can induce strain on its functional capacity needs further study.

Histological preparations of the seminal vesicle (Fig. 5) clearly demonstrate the difference in the villous mucosa. The villous mucosa gets obliterated and the primary, secondary and tertiary folds are not clearly visible in group II. The luminal volume increases and the lumen is vacuolated in group II .The smooth muscle layer

Table 3. Effect of Doxorubicin on the spermatogonial, spermatocyte and spermatid population (per 100 of total cells) of male white mice Mus musculus

\begin{tabular}{|c|c|c|c|}
\hline & Spermatogonia & Spermatocyte & Spermatid \\
\hline Group - I & $18.69 \pm 0.25(\mathrm{a})$ & $35.52 \pm 0.30(\mathrm{a})$ & $45.42 \pm 0.34(\mathrm{a})$ \\
\hline Group - II & $17.26 \pm 0.13(\mathrm{~b})$ & $33.78 \pm 0.26(\mathrm{~b})$ & $46.94 \pm 0.18(\mathrm{~b})$ \\
\hline Group - III & $16.60 \pm 0.49(\mathrm{c})$ & $32.65 \pm 0.43(\mathrm{c})$ & $43.30 \pm 0.72(\mathrm{c})$ \\
\hline
\end{tabular}

The given values are Mean $\pm S D$; Means within a column with different letters are significant $(p<0.05)$

"Doxorubicin on mice" http://www.indjst.org
T.Sridevi et al. Indian J.Sci.Technol. 
found in between the connective layer and the villous mucosa is thinner in the in the experimental. However these changes recuperate in group III. Hence it can be reasoned that even if the histological changes witnessed in group II probably impaired the function, the changes are transitory and could be reverted back to normal if sufficient withdrawal time is given.

\section{Cell count in testis sections}

The percentage cell count of spermatogonial, spermatocyte and spermatid population of the testis was done and the results are tabulated in Table 3 . All the three cell types showed a significant decrease in group II. The spermatogonial, spermatocyte and the spermatid values further decreased in group III. The decrease in the cell count further proves the reproductive toxicity of the drug Doxorubicin. Reduction in spermatogonial population is supported by Meistrich (1982) who has demonstrated that drugs like Doxorubicin causes killing of the spermatogonial stem cells. This finding is further supported by Russell and Russell (1991). Mouse testicular stem cells were killed at high doses (Lu \& Meistrich, 1979). Ward et al., (1988) demonstrated dose dependent damage to the seminiferous tubules,

which was reflected in the testicular and epididymal sperm content.

Though the testicular damage or injury due to doxorubicin is reversible in most cases (Shamberger et al., 1981), the values of the cell count further decreased in group III, and this may be because the time needed for the recuperation after the cessation of the administration of the drug and the values may return to the control value if sufficient time is given. Similar trend was obtained where the various enzymes like LDH, Glucokinase, acid phosphatase and alkaline phosphatase changed on the administration of Doxorubicin but reverted back to the control value (Sridevi, 2011).

\section{Volume of the testis tubules}

Volume and densities of tubular lumen and seminiferous epithelium can also give information about the degree of testicular damage as a consequence of germ cell death (Vendramini et al., 2010). Observation made on the volume of the seminiferous tubule and interstitial stroma of the testis were tabulated and shown in Fig 6.

The seminiferous tubule showed an insignificant increase in volume in the group II, which further decreased significantly in the group III when compared to group II.

Table 4. Effect of Doxorubicin on the chromosomes of bone marrow preparation of white mice Mus musculus.

\begin{tabular}{|c|c|c|c|}
\hline & Numerical Abberation & $\begin{array}{c}\text { Structural } \\
\text { Abberation }\end{array}$ & $\begin{array}{c}\text { Mitotic } \\
\text { Index }\end{array}$ \\
\hline Positive Control & $41.88 \pm 0.15(\mathrm{a})$ & $7.74 \pm 0.22(\mathrm{a})$ & 1.66 \\
\hline Negative Control & $1.04 \pm 0.016(\mathrm{~b})$ & $0.99 \pm 0.02(\mathrm{~b})$ & 11.12 \\
\hline Group II & $0.17 \pm 0.01(\mathrm{c})$ & $1.97 \pm 0.13(\mathrm{c})$ & 10.14 \\
\hline Group III & $1.71 \pm 0.006(\mathrm{c})$ & $1.68 \pm 0.04(\mathrm{c})$ & 11.09 \\
\hline
\end{tabular}

The given values are Mean $\pm S D$; Means within a column with different letters are significant $(p<0.05)$

Research article

(c)Indian Society for Education and Environment (iSee)
"Doxorubicin on mice" http://www.indjst.org
The interstitial stroma on the other hand showed a significant decrease in volume of group II. The value of group III showed a slight increase from group II but was however lesser than the control. According to Vendramini et al. (2010), the alteration to the volume of testis is indicative of injury to gonad. In general, germ cell death caused by anticancer drugs, including doxorubicin (Shinoda et al., 1999; Panaretakis, 2002), culminates with a reduction of morphometric parameters (Stump, 2004; Lirdi, 2008). The trend observed however indicates that given sufficient recuperation time the values for the group III returned almost to the normal value and may revert back to that of the control if sufficient time is given. The above argument is supported by Shamberger et al., (1981) who stated that the testicular injury is reversible in most cases.

\section{Volume of the epididymal tubules}

The volume of the epithelium, lumen, and stroma of the caput, corpus and the caudal portion of the epididymis are shown in the Fig. 6.

In general the caput, corpus and the cauda of the epididymis showed a decrease in the epithelial and stromal volume, in their experimental groups which increased in group III. The lumen in the three different epididymal region showed an increase in the experimental animals which is statistically significant. The volume of the lumen of group III decreased in comparison to the group II.

Knobil \& Neill (1988) observed secretion of proteins and other substances into the lumen of the epididymal epithelium. During Doxorubicin treatment there was decrease in epididymal sperm content (Ward et al., 1988). This could be the cause for increased luminal volume and a decline in epithelial volume.

\section{Observations from chromosomal study of bone marrow} cells

Chromosome preparation of bone marrow revealed several aberrations. Both structural and numerical aberrations were observed and the results were tabulated in the Table 4.

The common structural aberrations observed were chromatid deletion, chromatid breaks and translocation. Another structural aberration of less frequent occurrence was the ring chromosome. Numerical aberrations include diploid and triploid cells. Another complex aberration observed was pulverized chromatid. Doxorubicin was recorded to induce translocations (Meistrich, 1982), reciprocal translocations (De Luca et al., 1990), balanced chromosomal rearrangements (Meistrich, 1982) and sister chromatid exchanges.

The numerical and structural aberrations were observed in all groups. However, their frequency of occurrence varied. The data showed that both numerical and structural aberrations increased in group II when compared to that of the control. The group III
T.Sridevi et al. Indian J.Sci.Technol. 
showed a decline in aberration from that of the group I, the decrease being statistically insignificant. Meistrich et al., (1990) established that even at high doses of 6 $\mathrm{mg} / \mathrm{kg}$, Doxorubicin is a weak inducer of chromosomal aberration. The aberration in the experimental groups that was observed in our present study is probably because low dose employed.

\section{Conclusion}

The histological observations in the present studies showed no apparent damage to the testis, epididymis and the seminal vesicle in the present dosage. The corpus region showed a decrease in size with a deterioration of most of its tubules. The morphometric investigations showed a marginal decrease in the spermatogonial, spermatocyte and spermatid population. Chromosome analysis of the bone marrow cells exhibited certain aberrations that were not significant. At the dose designed in the present investigation all the changes observed were transitory and did not impair the normal functioning of the reproductive tissues. Therefore, it may be concluded that the sub lethal dosage used in the present study is relatively safe for the reproductive tissue. Reference

1. De Luca DJ, Dulout FN, Grillo C, Terreros NC and Andrien JM (1990) The induction of reciprocal translocations in mouse germ cells by chemicals and ionizing radiations III. Differential effect of two doses of Adriamycin combined with 5 or 9 Gy of gamma rays. Mutat. Res. 232(1) 17-21.

2. Elias H and Pauly JE (1966) Human microanatomy. 3 rd edn. Davis: Philadelphia.

3. Kamendulis LM and Corcoran GB (1994) DNA as a critical target in toxic cell death enhancement of dimethylnitrosamine cytotoxicity by DNA repair inhibitors. J. Pharmacol. Exp. Ther. 271(3), 1695-1698.

4. Knobil E and Neill J (1988) The physiology of reproduction. $2^{\text {nd }}$ Edi. Raven Press Ltd., NY. pp:8371119.

5. Lirdi LC, Stumpp T, Sasso-Cerri E and Miraglia SM (2008) Amifostine protective effect on cisplatin-treated rat testis. Anat. Rec. 291(7), 797-808.

6. Lu CC and Meistrich ML (1979) Cytotoxic effect of chemotherapeutic drugs on mouse testis cells. Cancer Res. 39, 3575-3582.

7. McGardy PJ (1993) The cancer problem in Oncology. Prentice Hall International. pp:33-35.

8. Meistrich ML (1982) Quantitative correlation between testicular stem cell survival, sperm production, and fertility in the mouse after treatment with different cytotoxic agents. J. Androl. 3, 58-68.

9. Meistrich $\mathrm{ML}$, van Beck ME, Liang JC, Johnson SL and Lu J (1990) Low levels of chromosome mutations in germ cells derived from Doxorubicin treated stem spematogonia in the mouse. Cancer Res. 50(2), 370374.

10. Murthy PBK and Rahiman A (1983) Chromosomal abnormalities in severely malnourished Indian children. Hirosh. J. Med. Sci. 32, 291-294.
11. Panaretakis $T$, Pokrovskaja $K$, Shoshan $M C$ and Grander $\mathrm{D}$ (2002) Activation of bak, bax, and $\mathrm{BH} 3$-only proteins in the apoptotic response to doxorubicin. J. Biol. Chem. 277, 44317-44326.

12. Patil LR and Balaraman R (2009) Effect of melatonin on Doxorubicin Induced testicular damage in rats. J. Pharm. Tech. Res. 1(3), 879-884.

13. Pearse AG (1980) Histochemistry: Theoretical and applied Vol. 1 and $2,4^{\text {th }}$ ed., Churchill Livingstone, Edinburgh.

14. Pearse AG (1985) Histochemistry: Theoretical and applied Vol. 1 and $2,4^{\text {th }}$ ed., Churchill Livingstone, Edinburgh.

15. Pristos CA, Sokoloff M and Gustafson DL (1992) PZ-51 (Ebselen) in vivo protection against Adriamycin induced mouse cardiac and hepatic lipid peroxidation and toxicity. Biochem.Pharmacol. 44(4), 839-841.

16. Russel LD and Russel JA (1991) Short term morphological response of rat testis to administration of five chemotherapeutic agents. Am. J. Anat.192,142-168.

17. Saalu LC, Togun VA, Oyewopo AO and RajiY (2006) Artificial cryptorchidism and the moderating effect of melatonin in Sprague- Dawley rats. J. Appl. Sci. 6, 28892894.

18. Shamberger RC, Sherins RJ and Rosenberg SA (1981) Effects of postoperative adjuvant chemotherapy and radiotherapy on testicular function in men undergoing treatment for soft tissue sarcoma. Cancer. 47, 23682374.

19. Shinoda K, Mitsumori K, Yasuhara K, Uneyama C, Onodera H, Hirose M and Uehara M (1999) Doxorubicin induces male germ cell apoptosis in rats. Arch. Toxicol. 73(4-5), 274-281.

20. Sonmez M, Turk G and Yagi K (2005) The effect of ascorbic acid supplementation on sperm quality, lipid peroxidation and testosterone levels of male Wistar rats. Theriogenol. 63, 2063-2072.

21. Sridevi T. (2011) Effect of doxorubicin on the biochemical activities of the male reproductive system of white mice, Mus musculus. Indian J. Sci. Technol. 4 (12), 1715-1720.

22. Stumpp T, Sasso-Cerri E, Freymüller E, Miraglia SM(2004) Apoptosis and testicular alterations in albino rats treated with etoposide during the prepubertal phase. Anat. $\operatorname{Rec}[A]$. 279, 611-622.

23.Vendramini V, Sasso-Cerri E and Miraglia SM (2010) Amifostine reduces the seminiferous epithelium damage in doxorubicin-treated prepubertal rats without improving the fertility status. Reproductive Biol \& Endocrinol. 8, 316.

24.Ward JA, Bardin CW, Knight M, Robinson J, Gumulus G and Morris D (1998) Delayed effect of Doxorubicin on spermatogenesis and endocrine function in rats. Reproductive Toxicol. 2, 117-126.

25.Weiss GR (1995) Clinical Oncology. Prentice Hall International. pp: 43-45
Research article

CIndian Society for Education and Environment (iSee)
"Doxorubicin on mice" http://www.indjst.org
T.Sridevi et al. Indian J.Sci.Technol. 